Review article

\title{
Magnetic resonance imaging in the assessment of acute stroke
}

Majda Handanovići ${ }^{*}$, Fuad Julardžija ${ }^{2,3}$, Adnan Šehić2,3, Amela Sofić4, Merim Jusufbegović ${ }^{5}$, Deniz Bulja ${ }^{5}$

${ }^{1}$ MSc student, Faculty of Health Studies, University of Sarajevo, Sarajevo, Bosnia and Herzegovina

${ }^{2}$ Department of radiology technologies, Faculty of Health Studies, University of Sarajevo, Sarajevo, Bosnia and Herzegovina

3 Institute for health development, Faculty of Health Studies, University of Sarajevo, Sarajevo, Bosnia and Herzegovina

${ }^{4}$ Radiology Department, General Hospital “Abdulah Nakaš“ Sarajevo, Sarajevo, Bosnia and Herzegovina

${ }^{5}$ Radiology clinic, Clinical center of Sarajevo University, Sarajevo, Sarajevo, Bosnia and Herzegovina

Corresponding author: Majda Handanović, Faculty of Health Studies, University of Sarajevo, Stjepana Tomića 1,71000 Sarajevo, Bosnia and Herzegovina e-mail: majda.h25@hotmail.com

Received: 10.09 .2021

Accepted:01.11.2021

DOI: https://doi.org/10.48026/issn.26373297.2021.12.1.2

\begin{abstract}
Introduction: Stroke is the second leading underlying cause of death globally and the leading cause of disability in adults. Stroke diagnosis should be performed quickly and efficiently to eliminate other potential causes of neurological deficits and to assess the time since the onset of clinical symptoms. Computed tomography (CT) and magnetic resonance imaging (MRI) are essential methods of detecting and evaluating stroke type and treatment options. Diffusion and perfusion MR imaging is recommended for early stroke diagnosis, as well as for the selection of patients for recanalization therapy, and is considered effective in assessing treatment outcomes. The objectives of this study were to demonstrate the diagnostic value of diffusion and perfusion imaging in the diagnosis of acute ischemic stroke, analyze the role of magnetic resonance imaging in the selection of patients with acute stroke for recanalization therapy, and assess the effect of acute stroke complicity.

Material and methods: The research is designed as a systematic review of the primary scientific research literature, which was published in English in relevant scientific databases (PubMed, Google Scholar, Medline) from 2014 to 2021.

Results: 14 scientific research papers were singled out and the general characteristics of the study were analyzed (country, authors, year of publication, title of the study, type of study, study objectives, research methods, results and conclusion). A quality assessment of the included studies with cohort design and randomized controlled studies was performed, and most belong to the category of high-quality studies with a smaller number of medium-quality studies. The overall percentage of detected AIS cases in isolated studies using the DWI and/or PWI sequence was $90.8 \%$. At the same time, the outcome of recanalization therapy was assessed using MRI studies (the number of patients who developed adverse events with functional data outcome 30 or 90 days after the procedure was observed). Comparison of MRI and CT imaging protocols provided data on the total percentage of detected acute stroke cases using CT imaging protocols (68.9\%) and MRI imaging protocols (88.5\%), which is why MRI is considered a superior method.
\end{abstract}

Conclusion: Although CT is a suitable method for visualizing bleeding and also for early differentiation of hemorrhagic from ischemic stroke, if MRI imaging is available, it is recommended to use DWI, PWI, MRA 12 sequences for a more accurate diagnosis of stroke in the acute phase.

Keywords: magnetic resonance imaging; acute stroke; computed tomography; diffusion; perfusion; recanalization therapy. 
Introduction

Magnetic resonance imaging (MRI) is a multiplanar imaging method that provides cross-sections of the human body in high resolution in all three planes (transverse, sagittal and coronal), which facilitates insight into pathological processes, such as stroke (1). With the help of MRI imaging protocol, it is possible to detect a stroke in the acute phase, as well as to distinguish ischemic from hemorrhagic, which makes this imaging method important for making treatment decisions (thrombolysis or thrombectomy). Multimodal magnetic resonance imaging involves the use of the following sequences:

- T2-weighted imaging (T2WI),

- fluid-attenuated inversion recovery (FLAIR),

- gradient echo imaging (GRE),

- MR angiography (MRA),

- diffusion-weighted imaging (DWI) and

- $\quad$ perfusion-weighted imaging (PWI) (2).

Ischemia changes the water content in the affected area of the brain by prolonging the T1 and T2 relaxation times and appears as a dark area (hyposignal) in the T1 sequence, while in the T2 sequence the infarct area is seen as a light area (hypersignal). The T2 FLAIR sequence removes the hypersignal from the cerebrospinal fluid, which improves the visualization of many cerebral lesions, including stroke (3). Diffusion is the most sensitive for early identification of ischemic stroke, a technique that can quantitatively analyze the degree of diffusion of free water molecules within tissues and that shows an ischemic lesion in hypersignal just minutes after the onset of stroke symptoms (1). Perfusion imaging is considered an excellent tool for assessing the penumbra, i.e. the area of the brain in which the flow is partially preserved and which can be saved from permanent damage if recanalization is performed in a timely manner (3). Among the advantages of MRI in the diagnosis of acute stroke is the fact that this imaging technique does not use ionizing radiation, as well as the fact that the ischemic stroke is seen on the MRI image much earlier than on the CT image. Disadvantages include the longer imaging time compared to $\mathrm{CT}$, the higher cost of the examination, and the fact that for some patients due to the presence of metal foreign bodies or implants, this examination is contraindicated $(3,4)$.

The objectives of this study were to demonstrate the diagnostic value of diffusion and perfusion imaging in the diagnosis of acute ischemic stroke, to analyze the role of magnetic resonance imaging in the selection of patients with acute stroke for recanalization therapy, and to evaluate the superiority of MRI and CT imaging protocols in the diagnosis of acute stroke.

\section{Material and methods}

The research is designed as a systematic review of the primary scientific literature, which was published in English in relevant scientific databases (PubMed, Google Scholar, Medline) from 2014 to 2021. First, a selection of 14 scientific research papers was made in which the general characteristics of the study were analyzed (country, authors, year of publication, title of the study, type of study, study objectives, research methods, results and conclusion). With the help of the PRISMA flow diagram, the flow of information through different phases of the systematic review is presented - through the number of identified, included and excluded studies, and the reasons for exclusion from the research (5). Criteria for inclusion in the research were scientific research papers published in English in relevant scientific databases in the period from 2014 to 2021, which were focused on the application of MRI in the diagnosis of acute stroke, then papers in which comparison of MRI and CT imaging protocols were made for the diagnosis of the already mentioned condition, and papers concerning the role of magnetic resonance as a method of imaging in the selection of patients and monitoring the effects of recanalization therapy (thrombolysis or thrombectomy). Exclusion criteria were scientific research papers published before 2014, papers that do not contain primary data, and papers that do not contain data on the use of MRI in acute stroke. The search keywords were: acute stroke, magnetic resonance imaging, diffusion, perfusion, recanalization treatment. 


\section{PRISMA mode}

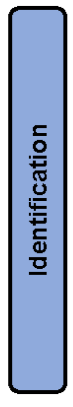

Ukupan broj potencijalnih naučno-istraživačkih radova identificiranih pretraživanjem baza podataka $(n=327)$

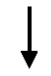

Broj radova identificiranih nakon uklanjanja duplikata $(n=289)$

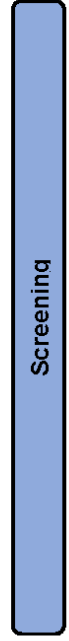
Radovi pregledan
sažetku ( $n=289$ )
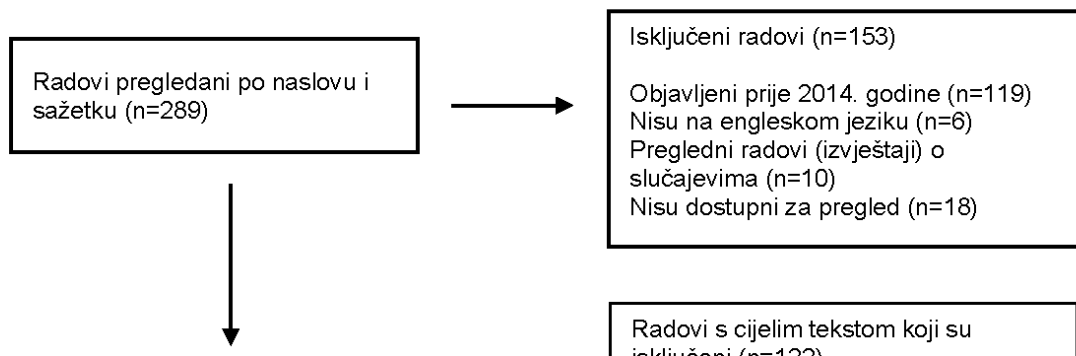

Radovi s cijelim tekstom koji se smatraju podobnim za istraživanje $(n=136)$ isključeni $(n=122)$

Samo sažetak/bez cijelog teksta $(\mathrm{n}=31)$

Ne prikazuju akutnu fazu moždanog udara $(n=46)$

Nema podataka o korištenju MRI u detekciji akutnog moždanog udara

$(n=23)$

Nema podataka o komparaciji imidžing protokola CT i MRI $(n=9)$

Nisu relevantni za dokazivanje ciljeva $(n=13)$

Studije uključene u sistematski pregled $(n=14)$

Diagram 1. PRISMA model 
Results

The quality assessment of the included cohort design studies (Table 1) was made according to the quality assessment tools developed by the National Heart, Lung and Blood Institute (NHLBI) in 2013, while the quality assessment of the included randomized controlled studies (Table 2) was also done according to the source mentioned above (6).

Table 1. Quality assessment of included studies with a cohort design

\begin{tabular}{|c|c|c|c|c|c|c|c|c|c|c|c|c|c|}
\hline Main author, year, country, title & 1 & 2 & 3 & 4 & 5 & 6 & 7 & 8 & 9 & 10 & 11 & 12 & $\begin{array}{c}\text { Total } \\
\text { assessment } \\
\text { quality }\end{array}$ \\
\hline $\begin{array}{l}\text { Simonsen CZ., et al., 2015, Denmark, } \\
\text { Sensitivity of Diffusion- and Perfusion- } \\
\text { Weighted Imaging for Diagnosing } \\
\text { Acute Ischemic Stroke Is } 97.5 \%\end{array}$ & $\mathrm{Y}$ & $\mathrm{U}$ & Y & $\mathrm{Y}$ & $\begin{array}{l}\mathrm{Y} \\
\mathrm{n}\end{array}$ & $\mathrm{Y}$ & $\mathrm{Y}$ & Y & Y & $\mathrm{Y}$ & $\mathrm{Y}$ & $\mathrm{Y}$ & High quality \\
\hline $\begin{array}{l}\text { Wolman D.N., et al, 2018, USA, Can } \\
\text { DWI and PWI alone accurately triage } \\
\text { anterior circulation acute ischemic } \\
\text { stroke patients to endovascular therapy? }\end{array}$ & $\mathrm{Y}$ & $\mathrm{U}$ & $\bar{Y}$ & $\mathrm{Y}$ & $\bar{Y}$ & $\mathrm{U}$ & $\mathrm{U}$ & $\mathrm{Y}$ & $\mathrm{Y}$ & $\mathrm{Y}$ & $\mathrm{Y}$ & $\mathrm{Y}$ & $\begin{array}{l}\text { Medium } \\
\text { quality }\end{array}$ \\
\hline $\begin{array}{l}\text { Aoki J., et al., 2015, USA, DWI Volume } \\
\text { as the Best Predictor of the } \\
\text { Diffusion-Perfusion Mismatch in Acute } \\
\text { Stroke Patients within } 8 \text { Hours of Onset }\end{array}$ & $\mathrm{Y}$ & $\mathrm{Y}$ & $\mathrm{Y}$ & $\bar{Y}$ & $\bar{Y}$ & $\mathrm{~N}$ & $\mathrm{~N}$ & $\mathrm{Y}$ & $\mathrm{Y}$ & $\mathrm{Y}$ & $\mathrm{Y}$ & $\mathrm{Y}$ & $\begin{array}{l}\text { Medium } \\
\text { quality }\end{array}$ \\
\hline $\begin{array}{l}\text { Harston GWJ., et al., 2017, USA, } \\
\text { Quantification of Serial Cerebral Blood } \\
\text { Flow in Acute Stroke Using Arterial } \\
\text { Spin Labeling }\end{array}$ & $\mathrm{Y}$ & $\mathrm{Y}$ & $\mathrm{Y}$ & $\mathrm{Y}$ & $\mathrm{Y}$ & $\mathrm{Y}$ & $\mathrm{Y}$ & $\mathrm{Y}$ & $\mathrm{Y}$ & $\mathrm{Y}$ & $\mathrm{Y}$ & Y & High quality \\
\hline $\begin{array}{l}\text { Kim JT.,et al., 2019, S. Korea, MRI } \\
\text { Versus CT Angiography Based Selection } \\
\text { for Endovascular Therapy } \\
\text { in Patients With Acute Ischemic Stroke }\end{array}$ & Y & $\mathrm{U}$ & $\mathrm{Y}$ & $\mathrm{Y}$ & $\mathrm{Y}$ & $\mathrm{Y}$ & $\mathrm{Y}$ & $\mathrm{Y}$ & $\mathrm{Y}$ & $\mathrm{Y}$ & $\mathrm{Y}$ & $\mathrm{Y}$ & High quality \\
\hline $\begin{array}{l}\text { Majidi S., et al., 2019, USA, MRI-based } \\
\text { thrombolytic therapy in patients with } \\
\text { acute ischemic stroke presenting with a } \\
\text { low NIHSS }\end{array}$ & $\mathrm{Y}$ & $\mathrm{Y}$ & $\mathrm{Y}$ & $\mathrm{Y}$ & $\mathrm{U}$ & $\mathrm{Y}$ & $\mathrm{Y}$ & $\mathrm{Y}$ & $\mathrm{Y}$ & $\mathrm{Y}$ & $\mathrm{Y}$ & $\mathrm{Y}$ & High quality \\
\hline $\begin{array}{l}\text { d'Esterre CD., et al., 2020, France, } \\
\text { Defining reperfusion post endovascular } \\
\text { therapy } \\
\text { in ischemic stroke using MR-dynamic } \\
\text { contrast enhanced perfusion }\end{array}$ & $\mathrm{Y}$ & $\mathrm{Y}$ & $\mathrm{Y}$ & $\mathrm{Y}$ & $\mathrm{Y}$ & $\mathrm{Y}$ & $\mathrm{N}$ & $\mathrm{Y}$ & $\mathrm{Y}$ & $\mathrm{Y}$ & $\mathrm{Y}$ & $\mathrm{Y}$ & High quality \\
\hline $\begin{array}{l}\text { Junejo HR., et al., 2021, Pakistan, } \\
\text { Predictive Value of CT Brain Perfusion } \\
\text { Studies in Acute Ischemic Infarct } \\
\text { Taking MRI Stroke Protocol As Gold } \\
\text { Standard }\end{array}$ & $\mathrm{Y}$ & $\mathrm{Y}$ & $\mathrm{Y}$ & $\mathrm{Y}$ & $\mathrm{Y}$ & $\mathrm{N}$ & $\mathrm{N}$ & $\mathrm{Y}$ & $\mathrm{Y}$ & $\bar{Y}$ & $\mathrm{Y}$ & $\mathrm{Y}$ & $\begin{array}{c}\text { Medium } \\
\text { quality }\end{array}$ \\
\hline $\begin{array}{l}\text { Copen WA, et al., 2017, USA, In } \\
\text { patients with suspected acute stroke, CT } \\
\text { perfusion-based cerebral blood flow } \\
\text { maps cannot substitute for DWI in } \\
\text { measuring the ischemic core }\end{array}$ & $\mathrm{Y}$ & $\mathrm{U}$ & $\mathrm{Y}$ & $\mathrm{Y}$ & $\bar{Y}$ & $\mathrm{Y}$ & $\mathrm{U}$ & $\mathrm{Y}$ & $\bar{Y}$ & $\mathrm{Y}$ & $\mathrm{Y}$ & $\mathrm{Y}$ & High quality \\
\hline $\begin{array}{l}\text { Schaefer PW., et al., 2015, USA, Limited } \\
\text { Reliability of Computed Tomographic } \\
\text { Perfusion Acute Infarct Volume } \\
\text { Measurements Compared With } \\
\begin{array}{l}\text { Diffusion-Weighted Imaging in } \\
\text { Anterior Circulation Stroke }\end{array} \\
\end{array}$ & $\mathrm{Y}$ & $\mathrm{U}$ & $\mathrm{Y}$ & $\mathrm{Y}$ & $\overline{\mathrm{U}}$ & $\mathrm{Y}$ & $\mathrm{U}$ & $\mathrm{Y}$ & $\mathrm{Y}$ & $\mathrm{Y}$ & $\mathrm{Y}$ & $\mathrm{Y}$ & $\begin{array}{l}\text { Medium } \\
\text { quality }\end{array}$ \\
\hline $\begin{array}{l}\text { Abdelgawad EA., et al., 2016, Egypt, } \\
\text { Diagnostic performance of CT cerebral } \\
\text { blood volume colour maps for } \\
\text { evaluation of acute infarcts; comparison } \\
\text { with diffusion-weighted MRI within } 12 \\
\text { hours of major stroke onset }\end{array}$ & $\mathrm{Y}$ & $\mathrm{Y}$ & $\mathrm{Y}$ & $\mathrm{Y}$ & $\bar{Y}$ & $\mathrm{~N}$ & $\mathrm{~N}$ & $\mathrm{Y}$ & $\mathrm{Y}$ & $\mathrm{Y}$ & $\mathrm{Y}$ & $\mathrm{Y}$ & $\begin{array}{l}\text { Medium } \\
\text { quality }\end{array}$ \\
\hline $\begin{array}{l}\text { Romero JM., et al., 2020, USA, Accuracy } \\
\text { of MRI T2*-weighted sequences (GRE- } \\
\text { EPI) compared } \\
\text { to CTA for detection of anterior } \\
\text { circulation large vessel thrombus }\end{array}$ & $\mathrm{Y}$ & $\mathrm{Y}$ & $\mathrm{Y}$ & $\mathrm{Y}$ & $\mathrm{Y}$ & $\mathrm{U}$ & $\mathrm{U}$ & Y & $\mathrm{Y}$ & $\mathrm{Y}$ & $\mathrm{Y}$ & $\mathrm{Y}$ & High quality \\
\hline
\end{tabular}


Checklist for cohorts studies: (1) Is the purpose of the study formulated? (2) Were subjects recruited for the cohort satisfactorily? (3) Was the exposure accurately measured? (4) Was the outcome accurately measured? (5) A. Have the authors identified all important confounders in the study's design and analysis? (5) B. Have the authors take into account known, possible confounders in the design and analysis of the study? (6) Were any of the people in the cohort followed up? (7) Were the people followed up long enough? 8) What is the result of this study? (9) Do you trust the results? (10) Can the results be transferred to practice? (11) Do the results of this study fit with the results of other available studies? (12) What are the implications of this study for practice? (answers Yes: Y; No: N; Unclear: U)

Table 2. Quality assessment of the included studies with an RCT design

\begin{tabular}{|c|c|c|c|c|c|c|c|c|c|c|c|c|}
\hline Main author, year, country, title & 1 & 2 & 3 & 4 & 5 & 6 & 7 & 8 & 9 & 10 & 11 & $\begin{array}{c}\text { Total } \\
\text { assessment } \\
\text { quality }\end{array}$ \\
\hline $\begin{array}{l}\text { Provost C., et al., 2019, France, } \\
\text { Magnetic Resonance Imaging or } \\
\text { Computed Tomography Before } \\
\text { Treatment in Acute Ischemic } \\
\text { Stroke Effect on Workflow and } \\
\text { Functional Outcome }\end{array}$ & $\mathrm{Y}$ & $\mathrm{Y}$ & $\mathrm{Y}$ & $\mathrm{Y}$ & $\mathrm{Y}$ & $\mathrm{Y}$ & $\mathrm{Y}$ & $\mathrm{Y}$ & $\mathrm{Y}$ & $\mathrm{U}$ & $\mathrm{Y}$ & High quality \\
\hline $\begin{array}{l}\text { Nael K., et al., 2017, USA, } \\
\text { Multiparametric Magnetic } \\
\text { Resonance Imaging for Prediction } \\
\text { of Parenchymal Hemorrhage in } \\
\text { Acute Ischemic Stroke After } \\
\text { Reperfusion Therapy }\end{array}$ & $\mathrm{Y}$ & $\mathrm{U}$ & $\mathrm{Y}$ & $\mathrm{Y}$ & $\mathrm{Y}$ & $\mathrm{Y}$ & $\mathrm{Y}$ & $\mathrm{Y}$ & $\mathrm{Y}$ & $\mathrm{Y}$ & $\mathrm{Y}$ & High quality \\
\hline
\end{tabular}

Checklist for RCT studies: (1) Is the purpose of the study clearly formulated? (2) Was the assignment to the different groups using a satisfactory randomization procedure? (3) Were all the participants reported at the end of the study? (4) Were participants, health-care providers, and study personnel "blind" to treatment? (5) Were the groups similar at the start of the trial? (6) Aside from the measure being evaluated (experimental intervention), were the groups treated equally? (7) What are the results? (8) How accurate are the results? (9) Can the results be transferred to practice? 10). Were all important outcomes measured in this study? (11) Are the benefits worth the harms and costs? (answers: Yes: Y; No: N; Unclear: U)

Table 3 analyzes the importance of diffusion and perfusion imaging in diagnosing acute ischemic stroke in these studies. It was observed through the number of patients in whom these imaging protocols successfully confirmed the aforementioned diagnosis in relation to the total number of patients included in research. This analysis provided data on the percentage of detected cases of acute ischemic stroke using the already mentioned protocols.

Table 3. Significance of diffusion (DWI) and perfusion (PWI) imaging in the diagnosis of acute ischemic stroke (AIS)

\begin{tabular}{|l|c|c|c|c|}
\hline \multicolumn{1}{|c|}{ Main author/year } & Total number of patients & $\begin{array}{c}\text { Pat. number in which the } \\
\text { DWI and/or PWI } \\
\text { confirmed the AIS }\end{array}$ & $\begin{array}{c}\text { Pat. number in which the } \\
\text { DWI and/or PWI didn't } \\
\text { confirm the AIS }\end{array}$ & $\begin{array}{c}\text { Percentage of detected } \\
\text { AIS cases using DWI } \\
\text { and/or PWI }\end{array}$ \\
\hline Simonsen CZ et al. (2015) & 565 & 518 & 47 & 11 \\
\hline Wolman DN et al. (2018) & 219 & 208 & 18 & $94.9 \%$ \\
\hline Majidi S et al. (2019) & 121 & 103 & 4 & $95.1 \%$ \\
\hline $\begin{array}{l}\text { Abdelgawad EA et al. } \\
(2016)\end{array}$ & 48 & 44 & $91.7 \%$ \\
\hline \multicolumn{5}{|c|}{ Total percentage (\%) of detected AIS cases using DWI and/or PWI sequence (90.8\%). } \\
\hline
\end{tabular}

When it comes to the role of MRI in the selection of patients with acute stroke for recanalization treatment and in the assessment of treatment outcomes, it was analyzed using Table 4 shown below. A modified Rankin scale (abbreviated $\mathrm{mRS}$ ) assesses the functional outcome 30 or 90 days after the recanalization treatment. 
Table 4. MRI as a tool for selecting patients diagnosed with AS for recanalization therapy and a tool for assessing the effect of the therapy on improving the health condition of treated patients

\begin{tabular}{|c|c|c|c|c|}
\hline $\begin{array}{l}\text { Main } \\
\text { author/year }\end{array}$ & $\begin{array}{l}\text { Pat. number who were } \\
\text { referred for rec.therapy } \\
\text { on the basis of MRI }\end{array}$ & $\begin{array}{c}\text { Mean NIHSS } \\
\text { value before } \\
\text { therapy }\end{array}$ & $\begin{array}{l}\text { The outcome of therapy in these } \\
\text { pat. recorded after control MRI } \\
\text { study }\end{array}$ & $\begin{array}{c}\text { Mean NIHSS } \\
\text { value after } \\
\text { therapy }\end{array}$ \\
\hline $\begin{array}{l}\text { Majidi S et al. } \\
\text { (2019) }\end{array}$ & 121 & $3(2-4)$ & $\begin{array}{l}\text { No bleeding ( } 104 \text { pat., } 86 \%) \text { HT (16 } \\
\text { pat., } 13.2 \%) \text {, sICH ( } 1 \text { pat, } 0.8 \%) \text {; } \\
\text { mRS } 0-1 \text { measured } 1 \text { month after } \\
\text { RT ( } 60 \text { pat., } 49.6 \%) \text { and } 90 \text { days ( } 49 \\
\text { pat., } 40.5 \%) \text {. }\end{array}$ & $1(0-2)$ \\
\hline $\begin{array}{l}\text { Nael K et al. } \\
(2017)\end{array}$ & 83 & $17(13-21)$ & $\begin{array}{l}\text { PH (20 pat., } 24.1 \%),(m R S>2) 3 \\
\text { months after RT }(15 \text { pat., } 18.1 \%) .\end{array}$ & ND \\
\hline $\begin{array}{l}\text { Kim JT et al. } \\
(2019)\end{array}$ & 986 & $14(11-18)$ & $\begin{array}{l}\text { Successful rec. (536 pat., } 54.4 \%) \text {, } \\
\text { sICH (29 pat., } 2.9 \%) \text {, mRS (0-2) } 3 \\
\text { months after RT ( } 289 \text { pat., } 29.3 \%) \text {, } \\
\text { mRS (0-1) } 3 \text { months after RT (168 } \\
\text { pat., } 17 \%) \text { death ( } 117 \text { pat., } 11.9 \%) .\end{array}$ & ND \\
\hline $\begin{array}{l}\text { Provost C et } \\
\text { al. }(2019)\end{array}$ & 299 & $18(14-21)$ & $\begin{array}{l}\text { mRS (0-2) } 3 \text { months after RT (153 } \\
\text { pat., } 51.2 \%) \text {, sICH ( } 4 \text { pat., } 1.3 \%) \text {, } \\
\text { death ( } 33 \text { pat., } 11 \%) \text {, successful rec } \\
\text { (73 pat., } 24 .+ \text { dž } 4 \%) \text {. }\end{array}$ & ND \\
\hline $\begin{array}{l}\text { dEsterre CD } \\
\text { et al. }(2020)\end{array}$ & 17 & $16(11-20)$ & $\begin{array}{l}\text { In } 15 \text { pat. established good } \\
\text { reperfusion (mTICI-2b / 3), at } 2 \\
\text { pat. weak or non-established } \\
\text { reperfusion (mTICI-0/1 / 2a). }\end{array}$ & $8(1-12)$ \\
\hline
\end{tabular}

List of abbreviations: HT (hemorrhagic transformation), sICH (symptomatic intracranial hemorrhage), mRS (modified Rankin scale), RT (recanalization therapy), PH (parenchymal hemorrhage), ND (no data), mTICI (modified treatment in cerebral ischemia score).

Table 5. Results of comparison of CT and MRI imaging protocols, as well as data on the percentage of detected cases of AS using the protocols listed below.

\begin{tabular}{|c|c|c|c|}
\hline Main author/year & $\begin{array}{l}\text { Compared CT imaging protocol and } \\
\text { percentage of detected cases of AS }\end{array}$ & $\begin{array}{c}\text { Compared MR imaging protocol } \\
\text { and percentage of detected cases of } \\
\text { AS }\end{array}$ & $\begin{array}{l}\text { Superior } \\
\text { imaging } \\
\text { protocol in } \\
\text { AS detection }\end{array}$ \\
\hline $\begin{array}{c}\text { Junejo HR et al. } \\
\text { (2021) }\end{array}$ & CTP (86/125 patients, $68.8 \%)$ & DWI (120/125 patients, 96\%) & DWI \\
\hline $\begin{array}{c}\text { Abdelgawad EA et al. } \\
\text { (2016) }\end{array}$ & CTP (30/48 patients, $62.5 \%)$ & DWI (44/48 patients, 91.7\%) & DWI \\
\hline $\begin{array}{c}\text { Copen WA et al. } \\
(2017)\end{array}$ & CTP (35/58 patients, $60.3 \%)$ & DWI (42/58 patients, $72 \%)$ & DWI \\
\hline $\begin{array}{c}\text { Romero JM et al. } \\
(2020)\end{array}$ & CTA (43/51 patients, $84.3 \%)$ & $\begin{array}{c}\text { T2*-W sequence (48/51 patients, } \\
94.1 \%)\end{array}$ & $\begin{array}{c}\mathrm{T} 2 *-\mathrm{W} \\
\text { sequence }\end{array}$ \\
\hline
\end{tabular}

List of abbreviations: CTP (computed tomography perfusion imaging), DWI (magnetic resonance diffusion imaging), CTA (computed tomography angiography), T2 $*$-W sequence (T2 * -weighted sequence, fast gradient echo sequence). 
Discussion

After assessing the quality of studies with cohort design, it can be concluded that most of them are in the category of high quality studies, with a smaller number of medium quality studies. Two randomized controlled trial studies were also evaluated as high quality studies. The most commonly used MRI imaging protocols in the studies included in the review were diffusion (DWI) and to a lesser extent perfusion (PWI). The diagnostic value of DWI in AIS detection was recognized and confirmed by the authors Zhang X.H. and Liang H.M. (7), who in a meta-analysis (13 studies) proved that the DWI sequence has higher sensitivity $(94.13 \%)$, specificity $(83.07 \%)$ and accuracy $(98.72 \%)$ in the detection of this disorder compared to standard and angiographic MRI and CT imaging. To what extent the modality by which patients were scanned influences the final decision on therapy was the main research question in the study by Hansen C.K. (8) and associates. They found that clinicians considered themselves more confident in their decision to select suitable candidates for i.v. thrombolysis if MRI rather than CT was used for imaging. MRI is also used to assess the effect of recanalization therapy through the number of identified patients in whom any hemorrhagic transformation (HT) has or has not occurred. Can MRI predict the occurrence of HT, author Suh C.H. (9) and associates sought to investigate by assessing the diagnostic performance of MRI in predicting HT in a meta-analysis (9 studies). The conclusion of their research, which included a total of 665 patients, was that MRI had a sensitivity of $92 \%$ and a specificity of $78 \%$ in the detection of HT. In his review Lövblada K.O. (10) with the help of associates evaluated which method (CT or MRI) is superior in the image of AS. He concluded that CT can detect early bleeding at the onset of stroke or after an intraarterial procedure, but that MRI is a more sensitive method in detecting changes in an ischemic lesion - especially in the case of small lesions, which are not sometimes visible on CT.

\section{Conclusion}

$18 \mathrm{CT}$ and MRI are diagnostic tools for determining the existence of stroke symptoms, the time of their occurrence, and whether they indicate ischemic or hemorrhagic stroke. CT is a good method for early distinguishing hemorrhagic from ischemic stroke, and its superior protocols are perfusion (CTP) and angiography (CTA). However, if MRI imaging is available, the use of diffusion (DWI), perfusion (PWI), and angiographic (MRA) sequences is recommended for a more accurate diagnosis of stroke in acute phase. With the help of MRI, it is possible to select suitable candidates with a diagnosis of AS for recanalization therapy, as well as to assess its effect on the improvement of the health condition of patients who have undergone therapeutic intervention.

\section{References}

1. Lee SH. Stroke revisited: Diagnosis and treatment of ischemic stroke. 1st ed., Singapore: Springer; 2017. str. 40-42.

2. Grotta JC, Albers GW, Broderick JP, Kasner SE, Lo EH, Mendelow A, et al. Stroke: Pathophysiology, Diagnosis and Management. 6th ed., New York: Elsevier; 2016. str. 768-772.

3. Caplan LR. Caplan's Stroke: A clinical approach. 5th ed., Cambridge: Cambridge University Press; 2016. str. 78-83.

4. Norrving B. Oxford textbook of stroke and cerebrovascular disease. 1st ed., New York: Oxford University Press; 2014. str. 94-98.

5. Page MJ, McKenzie JE, Bossuyt PM, Boutron I, Hoffmann TC, Mulrow CD, et al. The PRISMA 2020 statement: an updated guideline for reporting systematic reviews. BMJ [Internet]. 2021; 372:n71.

6. National Heart, Lung and Blood Institute (NHLBI). Study Quality Assessment Tools [Internet]. 2013 [pristupljeno 27.09.2021.]. Dostupno na: https://www.nhlbi.nih.gov/healthtopics/study-quality-assessment-tools

7. Zhang XH, Liang HM. Systematic review with network meta-analysis: Diagnostic values of ultrasonography, computed tomography, and magnetic resonance imaging in patients with ischemic stroke. Medicine [Internet]. 2019; 98(30):e16360.

8. Hansen CK, Christensen A, Rodgers H, Havsteen I, Kruuse C, Christensen H. Does the primary imaging modality-computed tomography or magnetic resonance imaging-influence stroke physicians' certainty on whether or not to give thrombolysis to randomized acute stroke patients? J Stroke Cerebrovasc Dis [Internet]. 2017; 27(4):926-935. 
9. Suh $\mathrm{CH}$, Jung $\mathrm{SC}$, Cho SJ, Woo DC, Oh WY, Lee JG, et al. MRI for prediction of hemorrhagic transformation in acute ischemic stroke: a systematic review and meta-analysis. Acta Radiol [Internet]. 2019; 61(7):964-972.

10. Lövblad KO, Altrichter S, Pereira VM, Vargas M, Gonzalez AM, Haller S, et al. Imaging of acute stroke: CT and/or MRI. J Neuroradiol [Internet]. 2014; 42(1):55-64.

11. Simonsen CZ, Madsen MH, Schmitz ML, Mikkelsen IK, Fisher M, Andersen G. Sensitivity of diffusion- and perfusionweighted imaging for diagnosing acute ischemic stroke is $97.5 \%$. Stroke [Internet]. 2015; 46(1):98-101.

12. Wolman DN, Iv M, Wintermark M, Zaharchuk G, Marks MP, Do HM, et al. Can diffusion- and perfusion-weighted imaging alone accurately triage anterior circulation acute ischemic stroke patients to endovascular therapy? J Neurointerv Surg [Internet]. 2018; 10(12):1132-1136.

13. Aoki J, Tateishi Y, Cummings CL, ChengChing E, Ruggieri P, Hussain MS, et al. Diffusion-Weighted Imaging Volume as the Best Predictor of the Diffusion-Perfusion Mismatch in Acute Stroke Patients within 8 Hours of Onset. J Neuroimaging [Internet]. 2015; 25:217-225.

14. Harston GWJ, Okell TW, Sheerin F, Schulz U, Mathieson P, Reckless I, et al. Quantification of Serial Cerebral Blood Flow in Acute Stroke Using Arterial Spin Labeling. Stroke [Internet]. 2017; 48(1):123130.

15. Kim JT, Cho BH, Choi KH, Park MS, Kim BJ, Park JM, et al. Magnetic Resonance Imaging Versus Computed Tomography Angiography Based Selection for Endovascular Therapy in patients With Acute Ischemic Stroke. Stroke [Internet]., 2019; 50(2):365-372.

16. Provost C, Soudant M, Legrand L, Hassen WB, Xie Y, Soize S. Magnetic resonance imaging or computed tomography before treatment in acute ischemic stroke: Effect on workflow and functional outcome. Stroke [Internet]., 2019; 50(3):659-664.

17. Majidi S, Luby M, Lynch JK, Hsia AW, Benson RT, Kalaria CP, et al. MRI-based thrombolytic therapy in patients with acute ischemic stroke presenting with a low NIHSS. Neurology [Internet]. 2019; 93(16):e1507-e1513.

18. Nael K, Knitter JR, Jahan R, Gornbein J, Ajani Z, Feng L, et al. Multiparametric Magnetic Resonance Imaging for Prediction of Parenchymal Hemorrhage in Acute Ischemic Stroke After Reperfusion Therapy. Stroke [Internet]. 2017; 48(3):664-670.

19. Abdelgawad EA, Higazi MM, Abdelbaky AO, Abdelghany HS. Diagnostic performance of CT cerebral blood volume colour maps for evaluation of acute infarcts; comparison with diffusion-weighted MRI within 12 hours of major stroke onset. J Neuroradiol [nternet]. 2016; 44(1):10-16.

20. Romero JM, Liberato ACP, Montes D, Barnaure I, Jing $\mathrm{Xu}$ J, Maza $\mathrm{N}$, et al. Accuracy of MRI T2*-weighted sequences (GRE-EPI) compared to CTA for detection of anterior circulation large vessel thrombus. Emerg Radiol [Internet]. 2020; 27(3):269275.

21. d'Esterre CD, Sah RG, Assis Z, Talai AS, Demchuk AM, Hill MD, et al. Defining reperfusion post endovascular therapy in ischemic stroke using MR-dynamic contrast enhanced perfusion. Br J Radiol [Internet]. 2020; 93(1116):20190890.

22. Junejo HR, Yusuf S, Zeb R, Zeb U, Zeb AA, Ali A. Predictive Value of CT Brain Perfusion Studies in Acute Ischemic Infarct Taking MRI Stroke Protocol As Gold Standard. Cureus [Internet]. 2021; 13(7): e16501.

23. Copen WA, Yoo AJ, Rost NS, Morais LT, Schaefer PW, Gonzalez RG, et al. In patients with suspected acute stroke, CT perfusion-based cerebral blood flow maps cannot substitute for DWI in measuring the ischemic core. PLoS ONE [Internet]. 2017; 12(11):e0188891.

24. Schaefer PW, Souza L, Kamalian S, Hirsch JA, Yoo AJ, Kamalian S, et al. Limited Reliability of Computed Tomographic Perfusion Acute Infarct Volume Measurements Compared With DiffusionWeighted Imaging in Anterior Circulation Stroke. Stroke [Internet]. 2015; 46(2):41924. 